\section{Monitoring the presence of genetically modified potato EH92-527-1 (BPS-25271-9) in commercial processed food}

\author{
Maria Giovanna Tilocca, ${ }^{1}$ \\ Gianfranca Serratrice, ${ }^{1}$ \\ Maria Agostina Oggiano, ${ }^{1}$ \\ Maria Rosalba Mancuso, Ilaria Mascia, ${ }^{2}$ \\ Edoardo Marongiu, ${ }^{1}$ Bruna Vodret ${ }^{1}$ \\ 'Dipartimento di Igiene degli Alimenti, \\ Istituto Zooprofilattico Sperimentale \\ della Sardegna, Sassari; ${ }^{2}$ Dipartimento \\ di Agraria, Università degli Studi \\ di Sassari, Italy
}

\section{Abstract}

The Amflora (EH92-527-1) potato is a genetically modified (GM) potato in which only starch of the amylopectin form is produced. This has been achieved by intervening with the biosynthesis of starch in this variety of potato. The Amflora potato is solely grown for the purposes of enhancing its industrial application. Although the Amflora potato is not fit for human consumption, the presence of the potato itself or any of its derived products in the food chain cannot be excluded, it should be considerate adventitious or technically unavoidable and can be accepted in a proportion no higher than $0.9 \%$. To achieve the goal of our work we analysed forty-five potato-derived products to evaluate transgenic potato presence by real time polymerase chain reaction, obtaining negative results. In order to verify the correct application of the law and to assure the quality for the consumer, it is necessary to continue GM monitoring to verify the adventitious presence itself in food.

\section{Introduction}

Amflora (EH92-527-1) is a genetically modified (GM) potato variety, Solanum tuberosum L. of the chemical company BASF (Ludwigshafen, Germany). The potato has a modified starch composition. In the conventional potato starch is composed of two main parts amylose and amylopectin, 20 and $80 \%$ respectively. While amylopectin is the required starch component for industrial purposes due to its thickening properties, amylose is the unwanted starch component due to its gelling properties that result in the dissolved potato starch being unstable. For this reason, the two components must be separated. Separating amylopectin and amylose in potato starch requires energy and water consumption which makes it uneconomical. Although potatoes by their nature produce a mixture of amylose and amylopectin, Amflora was genetically engineered to produce only the amylopectin component of starch. Amflora was developed by silencing the expression of the starch synthase protein (GBSS), using antisense strategy to eliminate the expression of amylose. A gene conferring kanamycin resistance (nptII) was used as a selectable marker. Since Amflora potato is not fit for human consumption, it is solely grown to improve the industrial applications of the potato (paper industry, textile industry, in adhesives and in construction materials) (Abdallah, 2010).

The placing of the GM potato EH92-527-1 (BPS-25271-9) on the market for cultivation and industrial uses has been approved by the Commission Decision 2010/135/EU, in accordance with Directive 2001/18/EC of the European Parliament and of the Council (European Commission, 2010a); whereas the Commission Decision 2010/136/EU, has authorised the placing on the market of feed produced from GM potato EH92-527-1 (BPS25271-9) and the adventitious and technically unavoidable presence of the potato in food and other feed products, under Regulation (EC) No 1829/2003 of the European Parliament and of the Council (Commission Decision, 2010b).

The aim of this study was to screen commercial processed containing potato derived products from both nation and international markets, in order to monitor and verify the adventitious presence of GM Amflora.

\section{Materials and Methods}

Forty-five samples of potato-derived products from different markets were investigated (Table 1). DNA extraction from frozen and dried potato was carried out in accordance with CTAB method validated by European Union Reference Laboratory for GM food and feed. The DNA of each sample was examined to verify potato-DNA by Real Time PCR by amplification of UDP-glucose pyrophosphorylase (UGPase) gene (Savini et al., 2006, 2010). The potential presence of GM potato in food matrices was detected by PCR screening for the nos terminator (T-nos) DNA sequence of nopaline synthase from Agrobacterium tumefaciens, according to
Correspondence: Maria Giovanna Tilocca, Dipartimento di Igiene degli Alimenti, Istituto Zooprofilattico Sperimentale della Sardegna, via Vienna 2, 09123 Sassari, Italy.

Tel./Fax: +39.079.2892332.

E-mail:mgtilocca@gmail.com

Key words: Solanum tuberosum, Amflora, Amylopectin, GBSS, RT PCR.

Received for publication: 30 April 2013.

Revision received: 17 September 2013.

Accepted for publication: 26 September 2013.

This work is licensed under a Creative Commons Attribution 3.0 License (by-nc 3.0).

(C) Copyright M.G. Tilocca et al., 2014

Licensee PAGEPress, Italy

Italian Journal of Food Safety 2014; 3:1628

doi:10.4081/ijfs.2014.1628

real-time PCR method for detection of T-nos (Permingeat et al., 2002).

\section{Results}

The amplification plot showed the presence of an 88bp fragment of the UGPase gene from Solanum tuberosum in all samples examined (Figure 1a). The PCR screening of nos terminator (T-nos) DNA sequence, of nopaline synthase from Agrobacterium tumefaciens, confirmed the total absence of Amflora potato in food matrices investigated, as showed in Figure 1b and Table 2.

\section{Discussion and Conclusions}

In order to verify the correct application of the law, it is required to constantly monitoring food matrices to safeguard the consumers. The European Regulations set the labelling requirements for all the GM organism-containing products (food and feed), with a tolerance threshold established at $0.9 \%$ for authorised GM organisms and at $0.5 \%$ for GM organisms under authorisation procedure (Regulation EC N.1829/2003; European Commission, 2003). Amflora is been marketed for industrial use but not authorised for human consumption, thus its presence can only be accepted with a tolerance threshold below $0.9 \%$, as an adventitious presence. The method used for DNAextraction of starch products from food 
Table 1. Potato-derived products investigated and their country of origin.

\begin{tabular}{lcc} 
Potato-derived & $\begin{array}{c}\text { Number } \\
\text { of samples }\end{array}$ & $\begin{array}{c}\text { Country of origin } \\
\text { products }\end{array}$ \\
Raw potato & 5 & Italy \\
Potato flour & 5 & Italy/Germany \\
\hline Mashed potato (frozen and dried) & 5 & Italy/Germany/France \\
Crisps & 5 & Italy/Germany \\
\hline Frozen fries chips & 5 & Italy/Germany/Canada \\
Frozen raw potatoes & 5 & Italy/Germany/Canada \\
\hline Bread-potato & 5 & Italy \\
Homemade potato-sweet & 5 & Italy \\
\hline Homemade potato-pasta & 5 & Italy \\
\hline
\end{tabular}

matrices is particularly suitable to provide a very good performance as confirmed by UGPase endogenous gene amplification, for all sample analysed (Figure 1a and Table 2). An high-quality potato-DNA is essential in order to achieve the subsequently real time PCR assays to verify the potential presence of GM material. Results are able to confirm the total absence of Amflora for the samples analysed so far. It is necessary to continue GM monitoring so as to assure consumers about the absence of Amflora in both local and imported food products.

\section{a) UGPase}

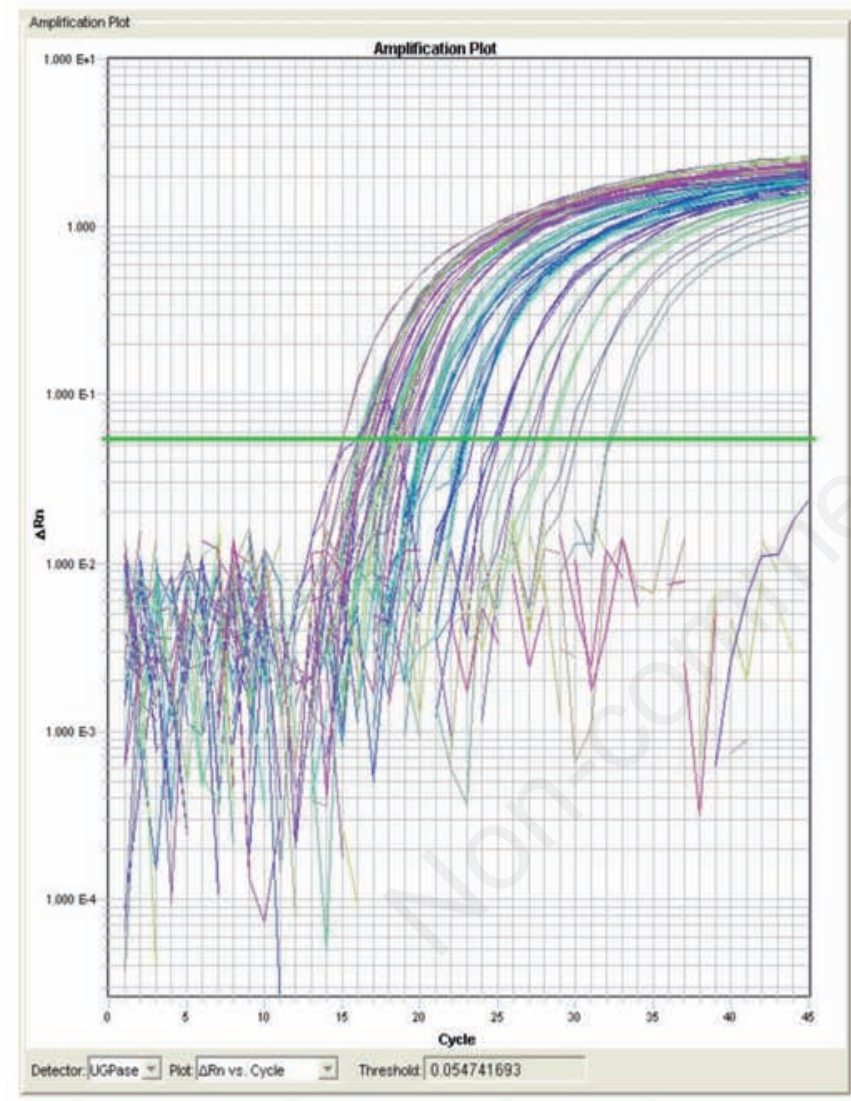

\section{b) tNOS}

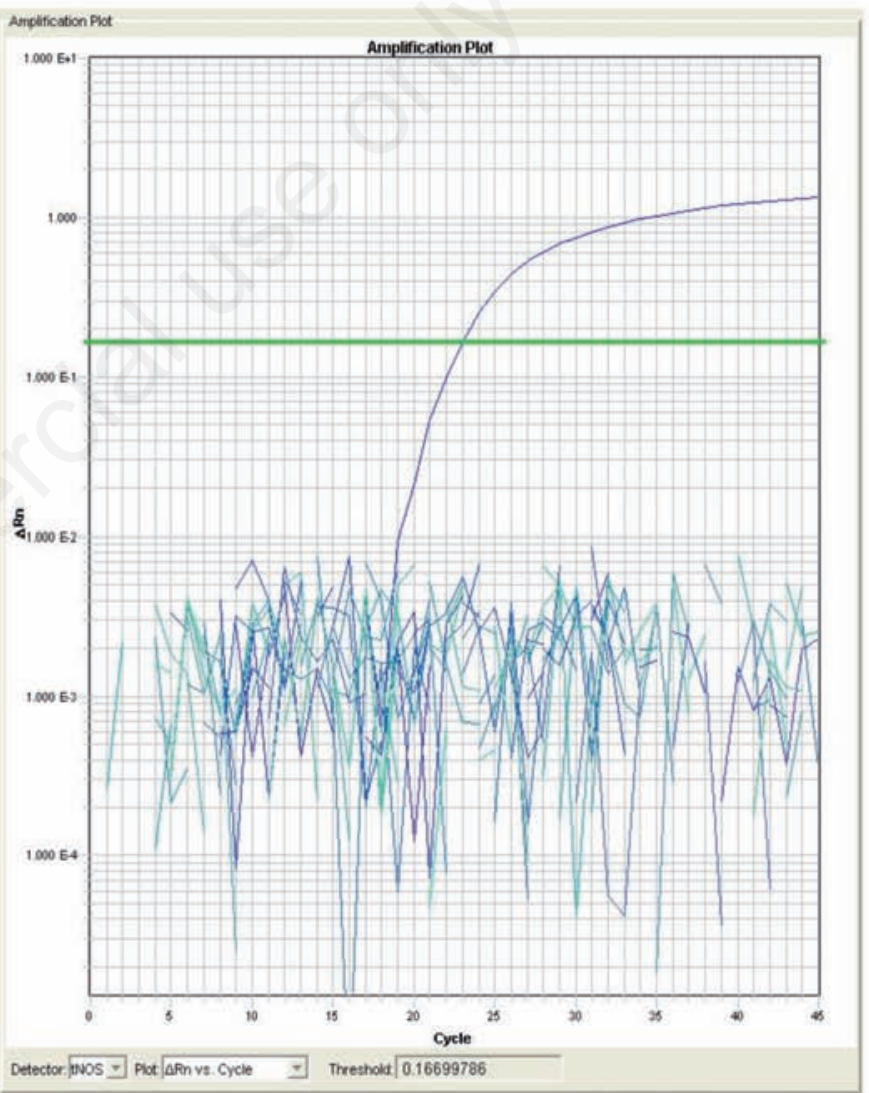

Figure 1. Amplification plot of UDP-glucose pyrophosphorylase gene (a) and nos terminator DNA sequence (b) in all samples examined. 
Table 2. Results obtained by real time polymerase chain reaction by amplification of UDP-glucose pyrophosphorylase gene and nos terminator DNA sequence in all samples investigated.

\begin{tabular}{|c|c|c|c|}
\hline Potato-derived products & $\begin{array}{c}\text { Number of investigated } \\
\text { samples }\end{array}$ & $\begin{array}{l}\text { UGPase number of } \\
\text { positive samples }\end{array}$ & $\begin{array}{l}\text { nos terminator (T-nos) } \\
\text { DNA sequence }\end{array}$ \\
\hline Raw potato & 5 & 5 & Absence \\
\hline Potato flour & 5 & 5 & Absence \\
\hline Mashed potato (frozen and dried) & 5 & 5 & Absence \\
\hline Crisps & 5 & 5 & Absence \\
\hline Frozen fries chips & 5 & 5 & Absence \\
\hline Frozen raw potatoes & 5 & 5 & Absence \\
\hline Bread-potato & 5 & 5 & Absence \\
\hline Homemade potato-sweet & 5 & 5 & Absence \\
\hline Homemade potato-pasta & 5 & 5 & Absence \\
\hline
\end{tabular}

\section{References}

Abdallah N, 2010. Amflora great expectations for GM crops in Europe. GM Crops 1:10912.

European Commission, 2003. Regulation of the European Parliament and of the Council of 22 September 2003 on genetically modified food and feed, 1829/2003/EC. In: Official Journal, L 268, 18/10/2003.

European Commission, 2010a. Commission Decision concerning the placing on the market, in accordance with Directive 2001/18/EC of the European Parliament and of the Council, of a potato product (Solanum tuberosum L. line EH92-527-1) genetically modified for enhanced content of the amylopectin component of starch, 2010/135/EU. In: Official Journal, L 53,
04/03/2010.

European Commission, 2010b. Commission Decision authorising the placing on the market of feed produced from the genetically modified potato EH92-527-1 (BPS25271-9) and the adventitious or technically unavoidable presence of the potato in food and other feed products under Regulation (EC) N. 1829/2003 of the European Parliament and of the Council, 2010/136/EU. In: Official Journal, L 53, 04/03/2010.

Permingeat HR, Reggiardo MI, Valleyos RH, 2002. Detection and quantification of transgenes in grains by multiplex and realtime PCR. J Agr Food Chem 50:4431-6.

Savini C, Foti N, Mazzara M, Charles Delobel C, Van Den Eede G, 2006. Event-specific method for the quantification of event EH92-527-1 potato using real-time PCR. Validation report and protocol-sampling and DNA extraction of potato. Method for DNA extraction from freeze and dried potato tubers. Joint Research-European Commission Biotechnology GMOs Unit ed., Varese, Italy. Available from: http://gmo-crl.jrc.ec.europa.eu/summaries/EH92-527-1-\%20Validation \%20Report.pdf

Savini C, Foti N, Mazzara M, Charles Delobel C, Van Den Eede G, 2010. Event-specific method for the quantification of event EH92-527-1 potato using real-time PCR. Validation report and protocol. PCR reactions set up and amplifications conditions. Joint Research-European Commission Biotechnology GMOs Unit ed., Varese, Italy. Available from: http://gmo-crl.jrc.ec. europa.eu/gmomethods/docs/QT-EVE-ST001.pdf 